\title{
The new office of the EU High Representative and the new European External Action Service
}

\author{
Piet Eeckhout
}

\section{Introduction}

The EU's external policies have long been marked by a political, institutional, and legal dichotomy between, on the one hand, external economic policies and on, the other, foreign and security policies, developed within the framework of the Common Foreign and Security Policy (CFSP). External economic policies have for a long time been the subject of a strong EU presence, in particular in the field of trade, which is an exclusive EU competence. Those policies involve not just the governments of the Member States, acting within the Council, but also the EU's supranational institutions, the Commission, the Court of Justice, and increasingly also the European Parliament. In fact, the EU's import and export regimes have been harmonized, indeed have been uniform, since the early nineties, with cars from Japan being one of the last sectors to become part of this uniform regime. By contrast, the Treaty of Maastricht introduced the CFSP as a separate EU pillar, governed by intergovernmental decision-making, and largely excluding the EU's supranational institutions. This has meant that the CFSP, though as a policy also predicated with the word 'common', has been very different in character from for example the common commercial policy. As an illustration, simply consider, for a moment, the contrast between the EU acting with a single voice on matters of trade, be it in the WTO, or in bilateral 
negotiations, for example with Japan - and the EU's policy in 2003 towards the international crisis leading to the invasion of Iraq:you will not easily find EU documents in 2003 on that crisis, for the simple reason that there was no EU common policy in any form or shape.

That does not mean, however, that the CFSP is an empty shell. The EU's foreign and security policy has developed and grown, to the point that the EU now regularly sends military missions to certain countries for the purpose of peace-making and peace-keeping. It is also very active in the field of economic, financial, and so-called smart sanctions, and has a strong counter-terrorism policy.

The pillar structure of the EU effectively created two parallel EU administrations. The Commission departments, responsible for trade matters, development co-operation, and external economic relations. And the Council Secretariat, headed by the previous High Representative, $\mathrm{Mr}$ Solana, responsible for the CFSP. Perhaps parallel administrations is not the best expression, because, much like government departments and institutions anywhere else in the world, the Commission and the Council have had their share of battles and turf wars.

There is however more at hand than mere standard inter - institutional rivalry. The EU's external policies are marked by some very prominent constitutional birth defects, which are difficult to remove. The CFSP aspires to cover "all areas of foreign policy" (Article 24(1) TEU), which for any non-informed observer would include trade relations and development co-operation. However, the policies in those areas have been constitutionally separated from the CFSP, and have been much stronger and effective than the CFSP. The latter was developed as a largely supplementary external policy, complementing the EU's strong external economic policies. Rather than foreign policy driving trade policy, one could have the impression that trade policy was driving foreign policy. The differences in decision-making mechanisms are very much part of that constitutional separation, and there has always been - and continues to 
The new office of the EU High Representative and the new European External Action Service (Eeckhout)

be - great fear in the Commission in particular that the CFSP would be used to undermine the supranational character of external economic policies. Where the Commission and the Council fight, the battle is often between supranationalism and intergovernmentalism, indeed between the EU itself, its common institutions, and national governments, interests and policies.

The Court of Justice has largely been the Commission's ally in these battles, because it has effectively determined and guaranteed that the CFSP remained within its complementary role, and did not trespass on first pillar territory. For example in the ECOWAS case, a couple of years ago, the Court found that financial support measures for ECOWAS (African) policies to combat the proliferation of small arms and light weapons had a development co-operation element to them, and could therefore not form part of the CFSP. Article 47 TEU (old version) provided that the CFSP could not affect EC policies.

The institutional rivalry as regards EU external policies (now officially called EU external action) became a matter of concern in the Convention on the Future of Europe, which drafted the ill-fated Constitutional Treaty. To bridge the institutional gap, the Convention came up with the idea of creating the office of the EU Minister for Foreign Affairs, with his or her famous double hat. The Minister would drive and direct both the CFSP and the EU's other external policies, and would therefore be based both within the Council and the Commission. It was never really clarified how the double hatting would work, though: would the minister have to wear two hats at once, one on top of the other, or would the minister simply have two hats to wear on different occasions? But leaving that vestimentary difficulty aside, the Convention at least attempted to bridge the institutional gap, and to sell this political innovation by referring to Henry Kissinger's famous exclamation: when there's a crisis, who do I call in Europe? Kissinger - or rather Kissinger's successors-would get the EU Minister's phone number. 
However, one may have doubts whether Kissinger's alleged exclamation ever became famous outside Europe. Moreover, the real issue is not so much whom the Americans need to call within the EU institutions (even today there is no single number, as we also have the Presidents of the European Council and of the Commission). The real issue is whether they call the EU or national capitals, as the Iraq crisis made crystal-clear. It is a great idea to bridge the institutional gap, but it is not obvious that that in itself will lead to a more effective, and a more common European foreign policy.

As is well known, the Constitution for Europe failed. But it was nicely repackaged as the Lisbon Treaty, after having been stripped of its constitutional terminology and imagery. The Minister had to go, and in came the High Representative of the Union for Foreign Affairs and Security Policy. However, the Lisbon Treaty did not really attempt to remove the constitutional birth defects which have marked EU external policies. The CFSP pillar is still standing, separate from the EU's other external policies. There has been some constitutional change as regards the relationship between these various policies. The main one is that $\mathrm{EU}$ external action is now subject to a single set of constitutional objectives, which should inspire, and indeed direct, all of the EU's external policies. But there is still a fundamental treaty provision, now Article 40 TEU, which aims to ensure that the intergovernmental CFSP does not trespass on the EU's supranational external economic policies. The only change there is that the demarcation now works in both directions. What this for example means, in legal terms, is that it is not clear whether the EU is capable of adopting a single legal act which has both CFSP and nonCFSP elements:the decision-making mechanisms continue to be very different, as well as the available legal instruments. External competences continue to be divided. 
The new office of the EU High Representative and the new European External Action Service

(Eeckhout)

\section{The High Representative}

So how could the office of the High Representative then bridge the institutional gap? The High Representative is instructed, by the TEU, to ensure the consistency of the EU's various external policies, and their consistency with internal policies. That instruction is also directed at the Council and the Commission. But the High Representative has not been given any real tools to avoid inconsistency, say between the CFSP and the EU's trade policies, other than her institutional presence in both the Council and the Commission. And she is by no means a sole actor. There continue to be Commissioners for trade and for development cooperation. Moreover, the European Council and Commission Presidents both have a role of their own, at least as regards external representation.

It therefore remains to be seen whether the High Representative office will be able to treat some of the constitutional birth defects. She will in any event be hard-pressed to find time to develop the right treatment. Indeed, the job description of the High Representative is most demanding, and one may have doubts whether a single office is capable of performing all of the assigned tasks.

The powers of the High Representative are much more extensive than those of her pre-Lisbon predecessor. An analysis of the provisions of the TEU referring to the High Representative show that there are, broadly speaking, five types of powers (understood in a broad sense as encompassing responsibilities and duties).

The first is a power to make proposals. Article 18(2) TEU, which speaks about the office in general terms, provides that the High Representative shall contribute by her proposals to the development of the CFSP. Further provisions refer to more specific rights of proposal. Article 22(2) TEU, concerning European Council decisions on the Union's strategic interests and objectives, provides that the High Representative and the 
Commission may submit joint proposals. Article 27(1) instructs the High Representative to contribute through her proposals towards the preparation of the CFSP. Along the same lines, Article 30(1) provides that the High Representative may refer any question relating to the CFSP to the Council. More specific rights of proposal concern the appointment of a special representative with a mandate in relation to particular policy issues (Article $33 \mathrm{TEU}$ ), and the setting up of a start-up fund for urgent financing of CFSP initiatives (Article 43(3) TEU).

The second power is that of chairing the Foreign Affairs Council (Article $27(1)$ ). Part of that power is the right to convene extraordinary Council meetings, in an emergency (Article 30(2)). There is no further indication of the role of the chair, but it is clear in any event that it is an important one, if only because the chair sets the agenda.

The third power is one of implementation and supervision. Article 18 (2) TEU already indicates that the High Representative 'shall conduct the Union's [CFSP]'. Article 24(1) similarly provides that the CFSP 'shall be put into effect' by the High Representative (and by the Member States), a phrase which is repeated in Article 26(3) TEU. Similarly, Article 27(1) provides that the High Representative shall ensure the implementation of the decisions adopted by the European Council and the Council.

Some more indication of what implementation of the CFSP involves is given by Article 24 TEU. That provision determines that the CFSP must be conducted within the framework of the (general) principles and objectives of external action, and that the policy must be based on the development of mutual political solidarity among Member States, the identification of questions of general interest, and the achievement of an ever-increasing degree of convergence (Article 24(2)). The Member States must support the Union's policy actively and unreservedly in a spirit of loyalty and mutual solidarity and must comply with Union action; they must also work together to enhance and develop their mutual political solidarity and refrain from any action contrary to the Union's 
The new office of the EU High Representative and the new European External Action Service (Eeckhout)

interests or likely to impair its effectiveness as a cohesive force in international relations (Article 24(3)). The provision ends by stating that the Council and the High Representative 'shall ensure compliance with these principles' (also Article 24(3); see also Article 26(3) TEU).

There is therefore also a supervisory and enforcement role for the High Representative, to some degree similar to the role of the Commission, in other areas of EU policy, 'to ensure the application of the Treaties' (Article 17(1) TEU). However, in contrast with the Commission, the High Representative has no legal means to ensure Member State compliance with the CFSP such as the opportunity to bring an action before the Court of Justice. It remains to be seen whether the limited political instruments in the hands of the High Representative will be sufficient for this purpose.

The High Representative also supervises the special representatives which may be appointed (Article 33 TEU). In the context of the Common Security and Defence Policy (CSDP) tasks referred to in Article 43(1) TEU (joint disarmament operations, humanitarian and rescue tasks, military advice and assistance tasks, etc), the High Representative shall ensure co-ordination of the civilian and military aspects of such tasks.

Lastly, under the heading of implementation and supervision one may also refer to the High Representative's duty regularly to consult the European Parliament on the main aspects and the basic choices of the CFSP and to inform it.

A fourth power - or duty in fact - concerns the Holy Grail of ensuring consistency in the EU's external action. Article 18(4) indicates that the fact that the High Representative is also one of the Commission's VicePresidents, responsible for Commission responsibilities in external relations, is aimed at ensuring such consistency. Article 21(3) TEU again emphasizes the need for consistency between the different areas of external action and between these and other EU policies, and instructs the Council and the Commission, assisted by the High Representative, to 
ensure that consistency and to co-operate to that effect.

A fifth power concerns the external representation of the EU as regards the CFSP, and co-ordination of external action by the Member States. Article 27(2) provides that the High Representative shall represent the Union for CFSP matters, and that she shall conduct political dialogue with third parties on the Union's behalf and shall express the Union's position in international organizations and at international conferences. Furthermore, Article 34(1) instructs the High Representative to organize the co-ordination of Member States action in international organizations and at international conferences. Article 34(3) envisages that the High Representative be invited to present the Union's position before the UN Security Council, when that position concerns a subject which is on the Security Council's agenda.

As can be seen, this is a tremendous range of powers and responsibilities. There can be serious doubts whether one person could ever accomplish all of those tasks. The High Representative is of course assisted, in particular by the EEAS. Delegation of some of the High Representative's functions will no doubt take place. Nevertheless, the combination of participation in the Commission's work, the chairing of the Foreign Affairs Council, and the external representation of the EU would seem a very tall order indeed.

\section{The European External Action Service}

The High Representative heads the new European External Action Service, which is in the process of being set up. From now on, the EU will have its own State Department, Foreign Office, or Ministry for Foreign Affairs - going by the new name of External Action Service. The institutional gap between the Commission and the Council is not only bridged by the High Representative, but also by a kind of shared administration. 
The new office of the EU High Representative and the new European External Action Service

(Eeckhout)

Article 27 (3) TEU provides that the High Representative shall be assisted by a European External Action Service, which shall work in cooperation with the diplomatic services of the Member States and shall comprise officials from relevant departments of the General Secretariat of the Council and of the Commission, as well as staff seconded from national diplomatic services of the Member States. The article further provides that the organization and functioning of the EEAS shall be established by a decision of the Council, acting on a proposal of the High Representative after consulting the European Parliament and after obtaining the consent of the Commission. As with the office of the High Representative, the idea is clearly to bridge the gap between the Commission and Council departments responsible for external action. However, the inclusion of diplomatic staff from the Member States also shows that this new EU diplomatic service is intended to build on and work in close co-operation with national administrations.

The EEAS was set up in July 2010 by Council decision, after an intense negotiation between the various institutions. It is beyond the scope of this overview to provide a full analysis of its genesis. It will no doubt take some time to see what the effects of the creation of this EU 'Foreign Office' will be on EU external action and what kind of role it may come to play.

The EEAS is set up as 'a functionally autonomous body of the European Union, separate from the General Secretariat of the Council and from the Commission with the legal capacity necessary to perform its tasks and attain its objectives' (Article 1(2) of the decision). It is placed under the authority of the High Representative (Article 1(3)) and is made up of a central administration and of the Union delegations to third countries and to international organizations (Article 1(4)). The inclusion of Union delegations is not as such provided for in the Treaties: Article 221 TFEU simply provides that Union delegations in third countries and at international organizations shall represent the Union, and that they 
shall be placed under the authority of the High Representative. However, it clearly makes institutional sense to integrate the Union delegations with the Brussels 'Foreign Office'.

As regards staff, the EEAS comprises officials and other servants of the EU, including personnel from the diplomatic services of the Member States appointed as temporary agents (Article 6(2)). As regards the Council, the departments and staff transferred are those covering the CFSP and the CSDP. As regards the Commission, the transfer includes nearly the entire Directorate-General (DG) for External Relations and parts of the DG for Development. This reflects to some extent the Commission portfolio of the current High Representative, which is limited to external relations. The Commission continues to have its own DGs for Development; Enlargement; Humanitarian Aid and Civil Protection; and Trade.

The task of the EEAS is, first of all, to support the High Representative (a) in fulfilling his or her CFSP and CSDP mandate; (b) in his or her capacity as President of the Foreign Affairs Council; and (c) in his or her capacity as Vice-President within the Commission (Article 2(1) of the EEAS decision). However, the EEAS shall also assist the President of the European Council, the President of the European Commission, and the Commission in the exercise of their respective functions in the area of external relations (Article 2(2)). When fulfilling those tasks, the EEAS must also co-operate with a range of institutions and actors. It must support, and work in co-operation with, the diplomatic services of the Member States, as well as the General Secretariat of the Council and the services of the Commission, in order to ensure consistency between the different areas of the Union's external action and between those areas and its policies (Article 3(1). The EEAS and the Commission services must consult each other on all matters relating to EU external action, except on matters covered by the CSDP. The EEAS must also extend appropriate support and co-operation to the other institutions and bodies of the 
The new office of the EU High Representative and the new European External Action Service (Eeckhout)

Union, in particular to the European Parliament (Article 3(4)).

The preamble to the EEAS decision emphasizes that the Parliament will fully play its role in the external action of the Union, including its functions of political control as provided for in Article 14(1) TEU, as well as in legislative and budgetary matters.

The EEAS decision also contains specific provisions on EU delegations. They shall comprise EEAS staff and, where appropriate for the implementation of the Union budget (which is a Commission responsibility) and Union policies other than those under the remit of the EEAS, Commission staff (Article 5(2)). The delegations therefore serve both the EEAS and the High Representative, on the one hand, and the Commission, on the other. This is exemplified by the provision which enables not only the High Representative and the EEAS to give instructions to heads of delegations, but also the Commission, in areas where the Commission exercises the powers conferred upon it by the Treaties' (Article 5(3)). Moreover, the Union delegations 'shall have the capacity to respond to the needs of other institutions of the Union, in particular the European Parliament, in their contacts with the international organizations or third countries to which the delegations are accredited'.

\section{Conclusions}

What conclusions can we draw at this point in time? The Treaty of Lisbon, which is effectively the re-packaged Constitutional Treaty, puts its faith nearly exclusively in institutional innovation as a tool to overcome some of the difficulties of EU external policy-making. The Treaty of Lisbon aimed to bring relief by homogenizing the institutional framework. The creation of the High Representative, heading a unified EEAS, appeared to make sense. The previous existence of parallel central administrations in the Council and the Commission was bound to be unproductive and to lead to turf battles rather than effective policy- 
making. There is however a risk that, instead of simplifying matters, the new framework has merely created a set of new institutional actors, and may not lead to greater interinstitutional harmony.

The institutional innovations have led to a frantic year in Brussels, in which the focus has mainly been on putting flesh to the new institutional bones. That process will certainly take some more time, but at some point the EU should move away from its institutional navel-gazing and focus on what role it can play in the world.

1) See P Eeckhout, The European Internal Market and International Trade (Oxford University Press 1994) ch 6.

2) Case C-91/05 Commission v. Council [2008] ECR I-3651.

3 ) Council Decision 2010/427 establishing the organizations and functioning of the European External Action Service [2010] OJ L201/30.

4 ) See further P Eeckhout, EU External Relations Law (2 ${ }^{\text {nd }}$ ed, Oxford University Press 2011) chs 5 and 11. 